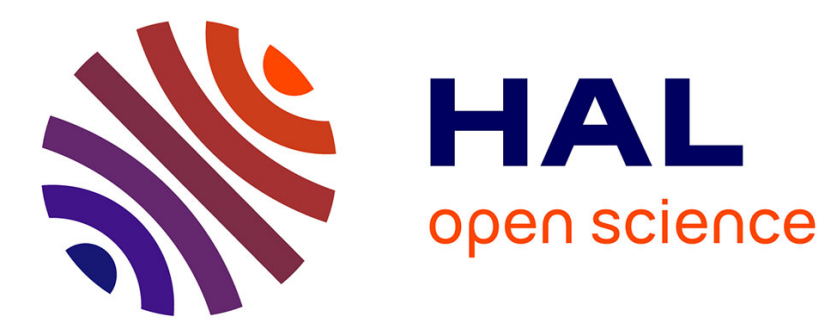

\title{
Extraction of plant proteins for two-dimensional electrophoresis
}

Fabienne F. Granier

\section{To cite this version:}

Fabienne F. Granier. Extraction of plant proteins for two-dimensional electrophoresis. Electrophoresis, 1988, 9 (11), pp.712-718. 10.1002/elps.1150091106 . hal-02727979

HAL Id: hal-02727979

https://hal.inrae.fr/hal-02727979

Submitted on 2 Jun 2020

HAL is a multi-disciplinary open access archive for the deposit and dissemination of scientific research documents, whether they are published or not. The documents may come from teaching and research institutions in France or abroad, or from public or private research centers.
L'archive ouverte pluridisciplinaire HAL, est destinée au dépôt et à la diffusion de documents scientifiques de niveau recherche, publiés ou non, émanant des établissements d'enseignement et de recherche français ou étrangers, des laboratoires publics ou privés. 
motin has been described in cell suspension, with characteristics similar to protein $b$. Both osmotin and $b^{\prime}$ are localized in the vacuole $[3,25,26,29]$ and accumulate in roots [25]. We are now testing these hypotheses.

Received May 24, 1988

\section{References}

[1] Meyer, Y., Aspart, L. and Chartier, Y., Plant Physiol., 1984, 75, 1028-1034.

(2) Meyer, Y., Aspart, L. and Chartier, Y., Plant Physiol. 1984, 75, 1035-1040.

[3] Meyer, Y., Chartier, Y, and Alibert, G., Plant Physiol. 1987, 83, 713-718.

[4] Meyer, Y. and Abel, W. O., Planta 1975, 125, 253-262.

[5] Murashige, T. and Skoog, F., Physiol. Plantarum. 1985, 19, 100-127.

[6] Jouanneau, J. P. and Tandeau de Marsac, N., Exp. Cell. Res. 1973, $77,167-174$.

[7] O'Farrell, P. Z., Goodman, H. M. and O'Farrell, P. H., 1977, 12, $1133-1142$

[8] Bradford, M., Anal. Biochem. 1976, 72, 248-254.

[9] Meyer, Y, and Chartier, Y., Plant Physiol. 1981, 68, 1273-1278.

[10] GAR-HRP Immun-Blot assay kit, Bio-Rad, 1987

[11] Vaitukaitis, J. L., Methods Enzymol. 1981, 73, 46-52.

[12] Fuhrmann, J. and Wollum, A. G., Appl. Environ.Microbiol. 1985,49, 1010-1013.
[13] Tasheva, B. and Desser, G., Anal. Biochem. 1983, 129, 98-102.

[14] Colas de Francs, C., Thiellement, H. and de Vienne, D., Plant Physiol. $1985,78,178-182$.

[15] Cremer, F., Vande Walle, C., AnalyticalBiochem. 1985, 147, 22-26.

[16] Damerval, C., de Vienne, D., Zivy, M. and Thiellement, H., Electrophoresis 1986, 7, 52-54.

[17] Wu, F. S. and Wang, M. Y., Anal. Biochem. 1984, 139, 100-103.

[18] Schuster, A. and Davies, E., Plant Physiol. 1983, 73, 809-816.

[19] Schuster, A. and Davies, E., Plant Physiol. 1983, 73, 822-827.

[20] Meyer, Y. and Chartier, Y., Plant Physiol. 1983, 72, 26-32.

[21] Kaufmann, S., Legrand, M., Geoffroy, P. and Fritig, B., EMBO 1987, $6,3209-3212$.

[22] Legrand, M., Kaufmann, S., Geoffroy, P. and Fritig, B., Proc. Natl. Acad. Sci. USA 1987, 84, 6750-6754.

[23] Mohnen, D., Shinshi, H., Felix, G. and Meins, F., EMBOJ. 1985, 4, 1631-1635.

[24] Shinshi, H., Mohnen, D. and Meins, F., Jr., Proc. Natl. Acad. Sci. USA, 1987, 84, 89-93.

[25] King, G., Hussey, C. and Turner, V., Plant Mol. Biol. 1986, 7, 441-449.

[26] King, G. J., Turner, V. A., Hussey, E., Wurtele, E. S. and Lee, S. M., Plant Mol. Biol. 1988, 10, 401-412.

[27] Singh, N. K., Handa, A. K., Hasegawa, P. M. and Bressan, R. A., Plant Physiol. 1985, 79, 126-137.

[28] Sing, N. K., Larosa, C., Handa, A. K., Hasegawa, P. M. and Bressan, R. A. Proc. Natl Acad Sci USA, 1987, 84, 739-743.

[29] Singh, N. K., Bracker, C. A., Hasegawa, P. M. Handa, A. K., Buckel, S., Hermodson, M. A., Pfankoch, E. D., Regnier, F. E. and Bressan, R. A., Plant Physiol. 1987, 85, 529-536.

\section{Fabienne Granier}

Laboratoire de Génétique des Systèmes Végétaux, La Ferme du Moulon, Gif-sur-Yvette

\section{Extraction of plant proteins for two-dimensional electrophoresis}

Three different extraction procedures for two-dimensional electrophoresis of plant proteins are compared: (i) extraction of soluble proteins with a nondenaturing Trisbuffer, (ii) denaturing extraction in presence of sodium dodecyl sulfate at elevated temperature allowing the solubilization of membrane proteins in addition to a recovery of soluble proteins, and (iii) a trichloroacetic acid-acetone procedure allowing the direct precipitation of total proteins.

\section{Introduction}

Two-dimensional polyacrylamide gel electrophoresis (2-D PAGE) of proteins according to O'Farrell [1] has become a widely used technique in various fields of plant biology such as analysis of gene expression during development, effects of

Correspondencè: Dr. Fabienne Granier, Laboratoire de Biologie de la Rhizosphère, CNRA, Route de Saint-Cyr, F-78026 Versailles Cedex, France

\footnotetext{
Abbreviations: 2-D PAGE, two-dimensional polyacrylamide gel electrophoresis; DTT, dithiothreitol; IEF, isoelectric focusing; LS, large subunit; NP-40, Nonidet P-40; PMSF, phenylmethylsulfonyl fluoride; PVP, polyvinylpyrrolidone; Rubisco, ribulose bisphosphate carboxylase/oxygenase; SDS, sodium dodecyl sulfate; TCA, trichloroacetic acid; UKS, urea-potassium carbonate-sodium dodecyl sulfate
}

growth substances, response to stress and the study of protein polymorphism. 2-D PAGE is the only technique allowing the resolution of several hundred gene products. Since the extraction of plant protein raised specific problems inherent to cell content, specific extraction methods have been developed.In comparison with animal tissues, plant tissues have a much lower protein content and the plant vacuole, which occupies a large volume of the cell, contains numerous compounds which have a deleterious effect during extraction $e . g$. organic acids, phenolic compounds, proteases, pigments, terpenes, inhibitory ions. Two main extraction procedures exist. (i) Nondenaturing extraction in presence of a buffer to compensate for the lowering of the $\mathrm{pH}$ when breaking cells allows the recovery of soluble proteins [2]; membrane-bound proteins can be recovered from the pellets. (ii) Denaturing extraction procedures allow simultaneous recovery of membrane-bound and 
soluble proteins. Denaturing extraction is based either on solubilization in presence of sodium dodecyl sulfate (SDS) [3], followed by protein precipitation or, alternatively, the proteins are directly precipitated by acetone [4], trichloroacetic acid (TCA) [5], or both [6], followed by solubilization in a buffer compatible with subsequent isoelectric focusing (IEF). Other procedures are phenol extraction [7] or direct extraction in a buffer suitable for IEF, like lysis buffer [1], or alkaline urea $[6,8,9]$. In our laboratory, we first used nondenaturing extraction [2] and observed in vitro protease activity [10]. To overcome this problem, we adopted an SDS procedure [3] which proved to be more efficient. Subsequently, Zivy [6] developed a new denaturing extraction procedure that also inhibited protease activity in wheat leaves. Since these extraction procedures were applied to samples of different origin (wheat and maize) and parallel to technical improvement of 2 D PAGE, spot-to-spot comparisons were not possible. In this paper, we compare the patterns of polypeptides extracted by three different procedures using large $2-D$ gels.

\section{Material and methods}

\subsection{Plant material}

Plant material used was flag leaf of maize hybrid F2 $\times$ F252 grown in the field and harvested at silking stage.

\subsection{Protein extraction}

\subsubsection{Tris-buffer extraction}

About $100 \mathrm{mg}$ of leaves were dry crushed in a mortar cooled with liquid nitrogen. The dry powder was resuspended in $2 \mathrm{~mL}$ of prechilled $\left(0^{\circ} \mathrm{C}\right)$ extraction buffer containing $30 \mathrm{~mm}$ Tris$\mathrm{HCl}, \mathrm{pH} 8.7,1 \mathrm{~mm}$ dithiothreitol (DTT), $1 \mathrm{~mm}$ ethylenediaminetetraacetic acid (EDTA), $1 \mathrm{mM}$ ascorbic acid, $5 \mathrm{~mm}$ $\mathrm{MgCl}_{2}$ and $10 \mathrm{mg}$ of insoluble polyvinylpyrrolidone (PVP). The extract was centrifuged twice at $35300 \mathrm{~g}$ (15 and $10 \mathrm{~min})$ and the supernatant recovered. Acetone $(8 \mathrm{~mL})$ with $0.07 \% 2$ mercaptoethanol was added to the supernatant and the mixture was stored at $-18^{\circ} \mathrm{C}$ for $1 \mathrm{~h}$. Precipitated proteins were then pelleted at $35300 \mathrm{~g}$ for $10 \mathrm{~min}$ [2]. The pellet was vacuum-dried for $l \mathrm{~h}$ and the proteins were solubilized in a ureapotassium carbonate-SDS (UKS) mixture $(50 \mu \mathrm{L} / \mathrm{mg}$ of dried pellet) [6], containing $9.5 \mathrm{M}$ urea, $5 \mathrm{~mm} \mathrm{~K}_{2} \mathrm{CO}_{3}, 1.25 \% \mathrm{SDS}$, $0.5 \%$ DTT, 2 \% Ampholine carrier ampholytes, $\mathrm{pH} 3.5-9.5$, $6 \%$ Triton X-100. After a 3-min centrifugation at $15000 \mathrm{~g}$ to remove insoluble materials, protein extracts were stored at $-80^{\circ} \mathrm{C}$.

\subsubsection{SDS extraction}

In this procedure, the extraction solution $(2 \mathrm{~mL}$ for $100 \mathrm{mg}$ of dry powder) contained $4 \%$ SDS, $5 \%$ 2-mercaptoethanol, $5 \%$ sucrose [3] and $10 \mathrm{mg}$ of insoluble PVP. Extracts were boiled for $3 \mathrm{~min}$ before centrifugation, the subsequent steps were identical with those described for Tris-buffer extraction.

\subsubsection{TCA-acetone extraction}

The dry crushed powder was mixed with $10 \mathrm{~mL}$ of $10 \%$ TCA, $0.07 \%$ 2-mercaptoethanol in cold acetone [6] and kept at $-18^{\circ} \mathrm{C}$ for $1 \mathrm{~h}$. After a 15 -min centrifugation at $35300 \mathrm{~g}$, the supernatant was removed and the pellet was rinsed for $1 \mathrm{~h}$ at $-18^{\circ} \mathrm{C}$ with $10 \mathrm{~mL}$ of cold acetone containing $0.07 \% 2$-mercaptoethanol. The rinsing solution was removed with caution and the pellet vacuum-dried for $1 \mathrm{~h}$. The pellet was resuspended in UKS solution (see Section 2.2.1) with $50 \mu \mathrm{L}$ of solubilization mixture per mg of dried pellet.

\subsection{Protein determination}

Proteins were assayed according to Scopes [11] by using the peptide bond absorption at $205 \mathrm{~nm}$.

\subsection{Electrophoresis}

The first-dimensional IEF was carried out in $24 \mathrm{~cm}$ long rod gels with a $1.5 \mathrm{~mm}$ diameter. The gel mixture was $4 \%$ acrylamide, $9.2 \mathrm{M}$ urea, $2 \%$ Triton $\mathrm{X}-100$ and $4 \%$ carrier ampholytes (1 part Pharmalyte, pH 5-6, and 3 parts Pharmalyte, $\mathrm{pH}$ 5-8). IEF was performed for $40000 \mathrm{Vh}$. Electrode solutions were $50 \mathrm{~mm}$ phosphoric acid at the anode and $50 \mathrm{~mm}$ sodium hydroxide at the cathode. Extract quantities deposited on top of the IEF gels were calculated according to protein measurement in order to have equal protein loading. These quantities were $22 \mu \mathrm{L}$ for Tris-buffer extracts, $27 \mu \mathrm{L}$ for SDS extracts and $50 \mu \mathrm{L}$ for TCA-acetone extracts. Gels were equilibrated for $15 \mathrm{~min}$ in $62.5 \mathrm{~mm}$ Tris- $\mathrm{HCl}, \mathrm{pH}$ $8.8,2.3 \%$ SDS and $10 \%$ sucrose. The second-dimensional SDS-electrophoresis was performed on slab gels $(215 \times 240 \times$ $1 \mathrm{~mm}$ ), bound to GelBond PAG (Marine Colloids). The gels contained $11 \%$ acrylamide, $0.5 \mathrm{M}$ Tris $\mathrm{HCl}, \mathrm{pH} 8.8,0.15 \%$ SDS and $1 \%$ sucrose. The IEF rod gels were sealed on top of the slab gels with agarose and electrophoresis was performed overnight in a Dalt tank [12] at $120 \mathrm{~V}$ with $25 \mathrm{~mm}$ Tris, $0.2 \mathrm{M}$ glycine and $0.1 \%$ SDS as buffer. Four 2-D gels were run with each extract. The 2-D gels were silver-stained using the apparatus described by Granier and de Vienne [13] with the modified technique of Damerval et al. [14], based on the procedure of Heukeshoven and Dernick [15]. The wash in water after ethanol was replaced by $2 \times 15 \mathrm{~min}$ washes in $0.3 \%$ sodium carbonate followed by $5 \mathrm{~min}$ in $0.05 \%$ sodium carbonate.

\section{Results and discussion}

\subsection{Comparison of different extraction procedures}

Patterns obtained with the different extraction procedures are shown in Fig. 1. The Tris-buffer and TCA-acetone patterns look similar, with a good resolution over the entire gel even for the most basic polypeptides, whereas the SDS pattern displays considerable streaking in the first dimension and inferior resolution. The number of spots reproducibly detected in the TCA-acetone pattern is 590 , while 531 spots are observed in the Tris and 563 in the SDS pattern. A more precise comparison between the TCA-acetone and Tris patterns (Fig. 2a) reveals many differences: among the 590 spots observed in the TCA-acetone pattern, 225 spots disappear in the Tris pattern, 23 spots decrease in intensity, 14 increase and 166 new spots appear; 328 spots are similar. Since the Tris procedure allows only the recovery of soluble proteins, membrane-bound proteins will be absent. Among the 225 spots disappearing in the 

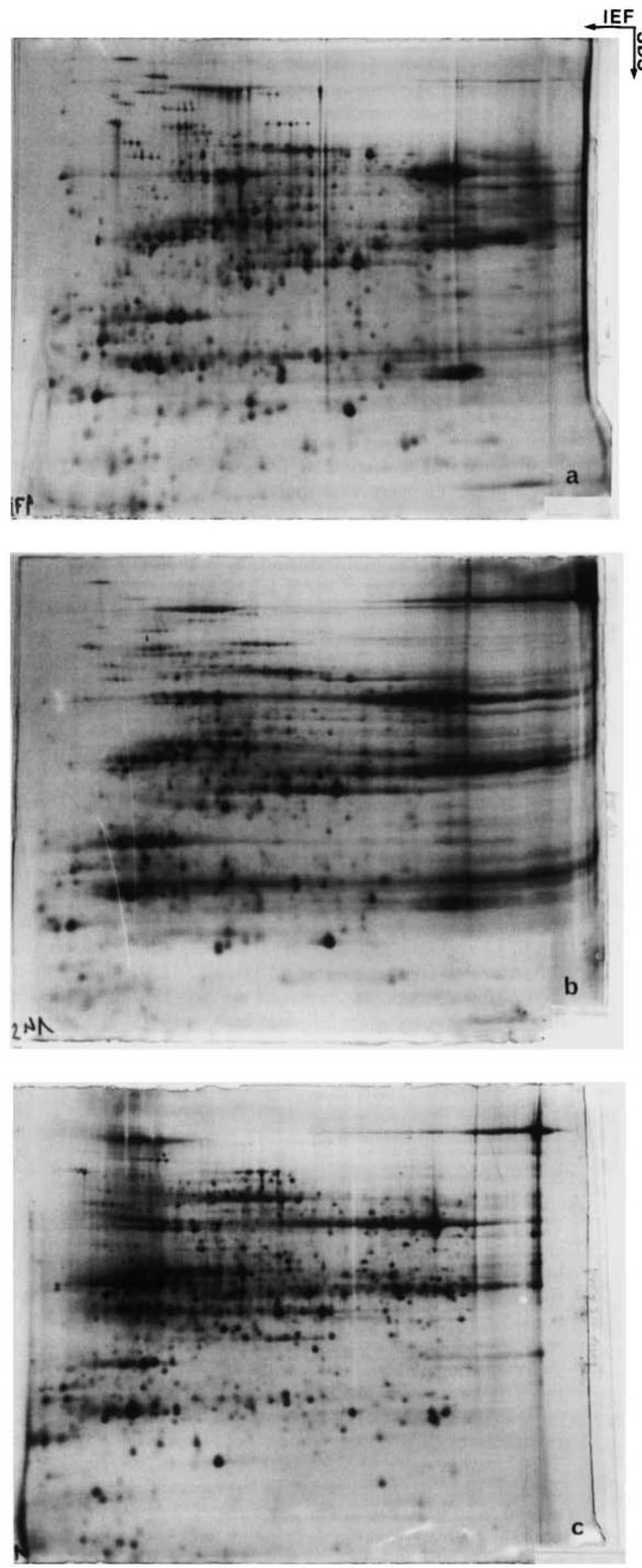

Figure 1. 2-D PAGE patterns of maize leaf proteins extracted by the: (a) TCA-acetone procedure, (b) SDS procedure, (c) Tris-buffer procedure. 


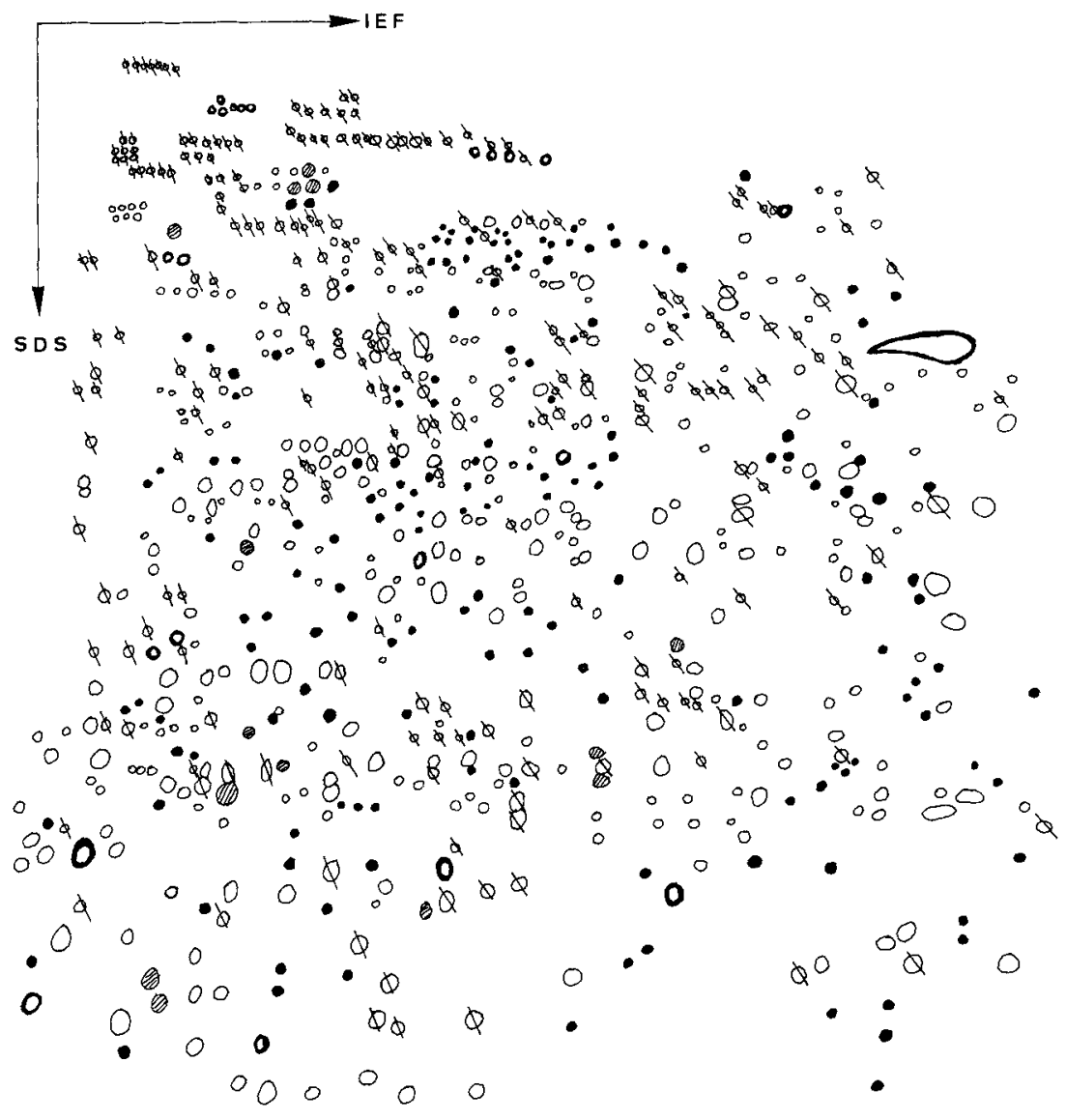

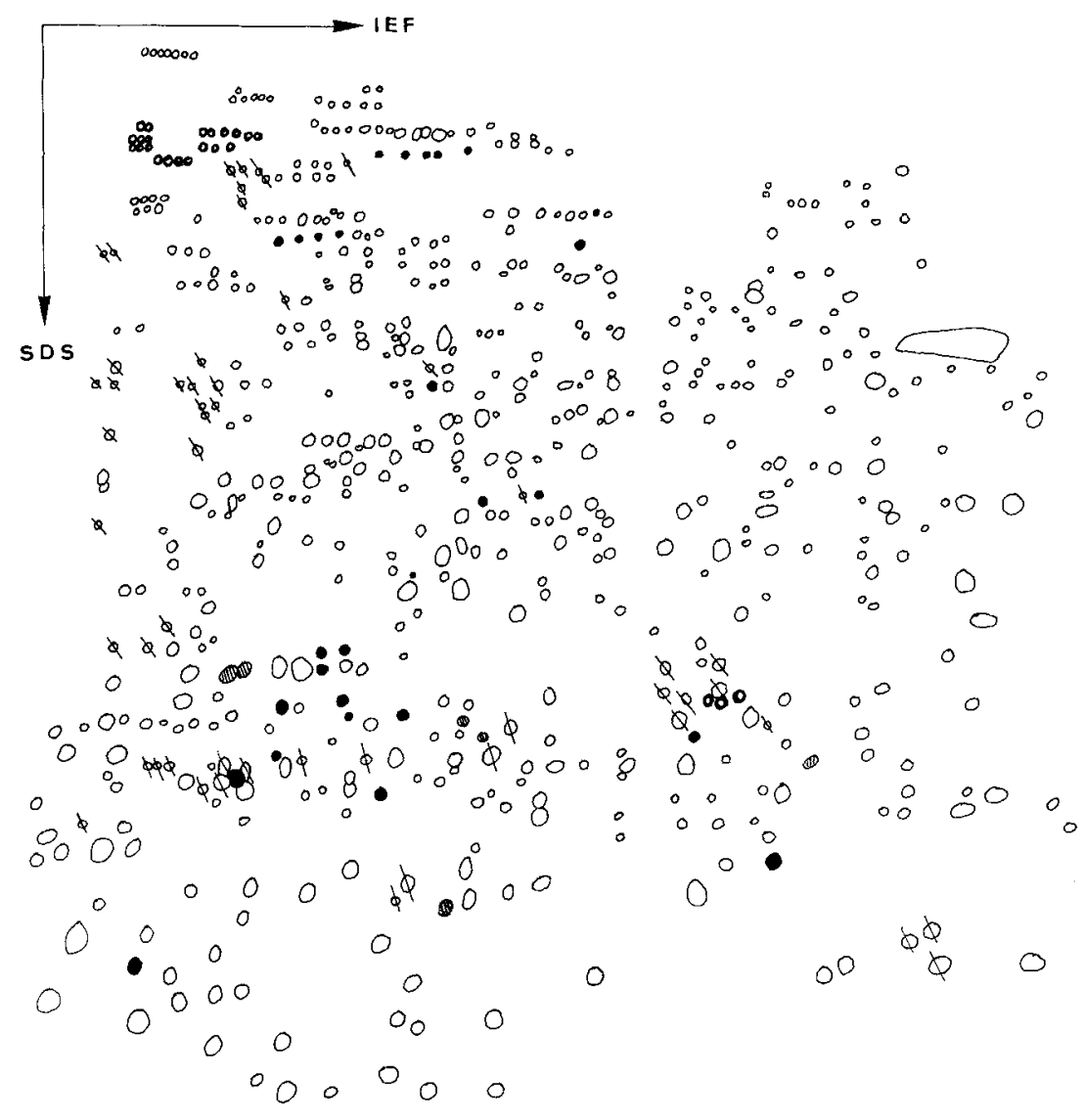

$b$

Figure 2. Comparison of 2-D patterns obtained by using three extraction procedures: (a) Tris versus TCAacetone pattern, (b) SDS versus TCA-acetone pattern. $\varnothing$ spots disappearing, spots appearing, spots with increased intensity, $\mathbf{O}$ spots with decreased intensity, on SDS and Tris patterns. 
Tris pattern, half are high molecular weight polypeptides, localized above the large subunit (LS) of the ribulose bisphosphate carboxylase/oxygenase (Rubisco). These spots may correspond, for the most part, to polypeptides degraded by proteolytic enzymes. The 166 new spots appearing in the Tris pattern are probably products of proteolytic digestion. None of them are above the Rubisco, most of them are middlesized polypeptides.

Comparison of the TCA-acetone with SDS pattern (Fig. 2b) reveals that they share a great number of polypeptides (507) but 53 spots present in the TCA-acetone pattern are absent in the SDS pattern, 6 spots increase in intensity, 24 decrease and 23 new spots appear in the SDS pattern. Most of the 53 spots disappearing are small in intensity. The 26 additional spots appearing in the SDS pattern may correspond to membranebound proteins, requiring a high temperature for solubilization. These proteins are not extracted with the TCA-acetone procedure.

\subsection{Nondenaturing extraction}

\subsubsection{Proteolytic degradation and protease inhibitors}

Tris extraction of soluble proteins was used by Zivy et al. $[2,16]$ to study cytoplasmic and nuclear genome expression in wheat. They noticed 24 spots, including the cytoplasmically encoded LS of Rubisco, to show an identical shift in the electropherograms of $T$. aestivum and Aegilops. They wondered if these spots were different products of the same cytoplasmic gene, resulting from degradation (by in vivo turnover or experimental procedure) or nonterminated translation intermediaries. In experiments with different protease inhibitors, single or combined, Colas des Francs et al. [10] observed that the intensity of these spots decreased. Most of these spots disappeared after SDS extraction, strongly suggesting that they represent products of in vitro degradation occuring during extraction. Moreover, immunoaffinity experiments showed that they were degradation products of LS. The moment when proteases are active could be determined. Tris-buffer extraction, followed by the SDS procedure, exhibited only minor degradation products. Samples kept for $2 \mathrm{~h}$ in Tris buffer at room temperature did not differ from samples treated rapidly, indicating that degradation is slow in this buffer. Proteolytic degradation occurred mainly in the lysis buffer, before proteases were degraded by autolysis or denaturated by urea.

Degradation by endogenous proteases occurring during nondenaturing extraction has been observed by numerous authors and, consequently most of them used protease inhibitors in their extraction buffer. Cashmore [17] used a serine protease inhibitor, phenylmethylsulfonyl fluoride (PMSF), at $1 \mathrm{~mm}$ level, to extract pea seedling proteins. Theillet et al. [18] working with Vicia faba root meristems, observed a dramatic degradation of polypeptides on Tris-buffer extraction. On screening a variety of protease inhibitors, in the presence or absence of SDS, they found PMSF, widely used by numerous authors [19-24], to have almost no effect. Combinations of inhibitors proved more efficient allowing $80 \%$ inhibition instead of only $50 \%$ maximum inhibition when just one inhibitor was used. The best mixture was $1 \mathrm{mM} N$-tosyl-Lphenylalanine chloromethyl ketone (TPCK), $5 \mathrm{mMN} N$-tosyl-Llysin chloromethyl ketone (TLCK), and $8 \mathrm{~mm}$ EDTA. For green tissues, Mayer et al. [25] found a mixture of $10 \mu \mathrm{g} / \mathrm{mL}$ leupeptin and $10 \mu \mathrm{g} / \mathrm{mL} \alpha_{2}$-macroglobulin to be effective. Dasgupta and Bewley [26] used $10 \mathrm{~mm}$ PMSF and $10 \mathrm{~mm}$ leupeptin for the extraction of soluble proteins from barley seedlings. Kenyon and Clanton [27] solubilized proteins from pineapple leaves in presence of $2 \mathrm{~mm}$-hydroxymercuribenzoate $(p-\mathrm{HMB})$ to inhibit proteolytic degradation even in presence of urea. Wu and Wang [5] also observed with petunia anthers having high protease activity, that none of the inhibitors had a universal inhibitory effect on proteases. Gallagher and Leonard [28] observed a proteolytic activity in the plasma membrane fraction of corn roots and in roots from other species. They investigated the effect of 12 inhibitors on extracts of corn root membrane-bound proteins and found that only PMSF ( $1 \mathrm{~mm}$ ) or chymostatine $(5 \mu \mathrm{g} / \mathrm{mL})$ allowed inhibition; however, none of them were efficient on oat roots. They concluded that it was essential to screen inhibitors in their capacity to reduce proteolysis specifically for each material and a particular protease inhibitor must be empirically optimized. Occasionally proteases do not present a problem and Meyer et al. |29| found no differences when the extractions were carried out in presence or absence of protease inhibitors, probably because tobacco mesophyll protoplasts seem to have only a low proteolytic activity.

Proteases may retain activity in urea even if protease inhibitors are addled to the extraction buffer $[18,30]$. Segers et al. [31] observed extensive protein degradation, with virtually no high molecular weight polypeptides and many low molecular weight polypeptides in the pattern, when proteins were extracted with the lysis buffer. Also in this case the protease inhibitors proved inefficient. The pH of the solubilization mixture was crucial. Whereas at neutral and acidic $\mathrm{pH}$ the degradation of high molecular weight polypeptides was pronounced, no proteolysis was found above $\mathrm{pH} 8.5$.

\subsubsection{Phenolic compounds}

Another serious problem encountered when proteins are extracted in presence of a nondenaturing buffer is due to phenolic compounds. Plant tissues are rich in phenolic compounds which mainly accumulate in vacuoles in various soluble forms. Generally, these compounds are more abundant in green tissues than in young seedlings or etiolated material. Oxidation of phenol compounds by phenoloxidases or peroxidases results in streaking [9]. Therefore phenol complexing agents such as PVP are added to the extraction buffers $[2,25,32]$ at a level varying from 1 to $200 \%$ for apical buds of white mustard plantlets [33]. Alternatively, or sometimes in combination with PVP, reducing agents such as 1-250 mM ascorbate $[25,32-34], 1-7.5 \% \mathrm{v} / \mathrm{v} 2$-mercaptoethanol [ 17 , $19,21,22,35,36], 2.5 \mathrm{~mm}$ potassium metabisulfite [23], 1-100 mM DTT $[2,25]^{2}$ are often added to prevent phenoloxidase activity. None of the inhibitors added during pine needle extraction were efficient in preventing phenol oxidation. When a Tris-buffer was used to extract proteins from Douglas fir needles, a material rich in phenols and terpens, brownish extracts, due to phenol oxidation, were obtained. None of the additives tested (germanium dioxide, sodium tetraborate, 2-mercaptoethanol) proved efficient and all pattern displayed considerable streaking and poor resolution. With SDS extraction, phenoloxidases could immediately be inactivated and well-resolved gels were obtained [37]. 


\subsection{Denaturing extraction in presence of detergents}

Both proteases and phenoloxidases could efficiently be inactivated by denaturing extraction in the presence of SDS, improving the reproducibility of patterns and limiting the appearance of artefactual spots. SDS extraction, with boiling of the sample, and an acetone precipitation step was developed by Harrison and Black [3] to extract proteins of bundle sheath and mesophyll cells of Digitaria sanguinalis. While SDS affords the advantage of destroying enzymatic activities in some cases, its application may result in streaking as previously observed [30,31] and as can be seen on Fig. 1. Surprisingly, some authors found a residual protease activity even in presence of SDS $[5,38,39]$ that can hydrolyze proteins because of increased availability of cleavage sites produced by the SDS treatment. Wu and Wang [5] observed a proteolytic degradation of petunia anther proteins even in presence of SDS and protease inhibitors. Boiling the samples in presence of SDS inactivated proteases but Gallagher and Leonard [28] found that this caused aggregation of high molecular weight polypeptides. Alterations induced by heat are a specific problem for transport ATPases and has been described for the catalytically active subunit of yeast plasma membrane ATPase [40]. A loss of resolution due to heating has been observed for the catalytic subunit of the $\mathrm{Na} / \mathrm{K}$ ATPase [41] and Neurospora ATPase [42]. Dhugga et al. [43] did not observe this aggregation upon heating to $75^{\circ} \mathrm{C}$.

In addition to enzyme inactivation, SDS is also an excellent solubilizing agent and in contrast to Tris extraction, it allows the recovery of membrane-bound proteins. Many membrane proteins are insoluble in urea and non-ionic detergents, or even in anionic detergent if extracted without heating. With SDS optimum solubilization was achieved by heating the samples for $3 \mathrm{~min}$ at $100^{\circ} \mathrm{C}$. Ames and Nikaido [44] solubilized membrane proteins of Salmonella typhimurium with hot SDS because the O'Farrell's lysis buffer [1] was not efficient. Horst et al. [8] found an efficient solubilizing effect for seed membrane proteins, without using SDS, for a combination of urea and Nonidet P-40 (NP-40) with potassium carbonate at $\mathrm{pH}$ 10.3. This method was used to solubilize brain proteins, which are normally insoluble, offering the advantage that extracts can be directly applied to IEF gels. With green leaves of tobacco, this method was unsatisfactory and required an additional acetone precipitation step allowing the removal of pigments, phenols and lipids [9]. With this modification, streaking could be eliminated.

\subsection{Phenol extraction}

Some authors used a phenol extraction of proteins which inactivates enzymes without heating. This method has been developed by Schuster and Davis [7] and has been used successfully by numerous authors with different materials, such as leaves of spinach seedlings [45], barley roots and shoots [46]. This method consists of a Tris-buffer extraction to which an equal volume of water-saturated phenol is added, followed by separation of the two phases by centrifugation. Hurkman and Tanaka $[30]$ found this technique to yield well-resolved protein spots and gels free of streaking and smearing. The solubilization of membrane proteins is as good as that obtained with SDS. In addition, this method allows the removal of polysaccharides, a potentially detrimental component in plant extracts. Phenol extraction also removed large glycoproteins
[47]. Moreover, this technique also allows the extraction of nucleic acids which are partitioned in the aqueous phase. The disturbing background staining, often observed with other extraction procedures, disappeared. The major disadvantage is that it is time-consuming.

\subsection{Direct precipitation}

Direct precipitation of total proteins allows immediate inactivation of proteases and phenoloxidases. Good results were obtained with petunia anthers and other plant tissues with high protease activity [5] with $10 \% \mathrm{w} / \mathrm{v}$ TCA precipitation, followed by rinses with acetone. Acetone precipitation was used by Vierling and Key [4]. A combination of these two precipitating and denaturing agents was used by Zivy [6]. Using precipitation in $10 \%$ TCA in cold acetone followed by rinses with acetone to eliminate TCA, good quality gels were obtained (see Fig. 1). This method must necessarily be followed by a solubilization procedure efficient for all proteins. With O'Farrell's lysis buffer [1] there is incomplete solubilization of membrane proteins with resultant streaking. Addition of potassium carbonate to urea allowed the solubilization of normally insoluble brain proteins [8]. Envelope membrane pellets or stromal proteins of chloroplasts from Pisum sativum were solubilized with this buffer and gave good quality 2-D gels [48]. Improved solubilization was achieved by adding $0.5 \%$ SDS [3] to the O'Farrell's lysis buffer [1]. A combination of the solubilizing effect of these different compounds (urea and Triton X-100 with potassium carbonate and SDS) allowed a better solubilization of proteins before IEF [49], improving the gel quality in the basic range.

The TCA-acetone procedure followed by resolubilization in UKS is a method allowing visualization of total proteins without artefacts due to protease or phenoloxidase action. This procedure has been tested in the laboratory with different materials: tomato, petunia, latex, coconut pollen, wheat, maize, sunflower, yeast and even with animal material such as nematodes. Gels obtained are always well-resolved, free of smearing and streaking. As compared with phenol extraction, it is fast and thus is particularly suitable when numerous samples have to be prepared, which is the case, for example, in studies of genetic polymorphism.

Received August 1, 1988

\section{References}

[1] O'Farrell, P. H., J. Biol. Chem. 1975, 250, 4007-4021.

[2] Zivy, M., Thiellement, H., de Vienne, D. and Hofmann, J.-P., Theor. Appl. Genet. 1983, 66, 1-7.

[3] Harrison, P. A. and Black, C. C., Plant Physiol. 1982, 70, 1359-1366.

[4] Vierling, E. and Key, J. L., Plant Physiol. 1985, 78, 155-162.

[5] Wu, F.-S. and Wang, M.-Y., Anal. Biochem. 1984, 139, 100-103.

[6] Zivy, M., in: Galteau, M. M. and Siest, C. (Eds.), Electrophorèse bidimensionnelle, Presses Universitaires, Nancy 1986, pp. 69-72.

[7] Schuster, A. M. and Davies, E., Plant Physiol. 1983, 73, 809-816.

[8] Horst, M. N., Basha, S. M. M., Baumbach, G. A., Mansfield, E. H. and Roberts, R. M., Anal. Biochem. 1980, 102, 399-408.

[9] Hari, V., Anal. Biochem. 1981, 113, 332-335.

$110]$ Colas des Francs, C., Thiellement, H. and de Vienne, D., Plant Physiol. 1985, 78, 178-182.

[11] Scopes, R. K., Anal. Biochem. 1974, 59, 277-282. 
[12] Anderson, N. L. and Anderson, N. G., Anal. Biochem. 1978, 85, 341-354.

[13] Granier, F. and de Vienne, D., Anal. Biochem. 1986, 155, 45-50.

[14] Damerval, C., le Guilloux, M., Blaisonneau, J. and de Vienne, D., Electrophoresis 1987, 8, 158-159.

[15] Heukeshoven, J, and Dernick, R., Electrophoresis 1985,6, 103-112.

[16] Zivy, M., Thiellement, H., de Vienne, D. and Hofmann, J.-P., Theor. Appl. Genet. 1984, 68, 335-345.

[17] Cashmore, A. R., J. Biol. Chem. 1976, 251, 2848-2853.

[18] Theillet, C., Delpeyroux, F., Fiszman, M., Reigner, P. and Esnault, R., Planta 1982, 155, 478-485.

[19] Meza-Basso, L., Alberdi, M., Raynal, M., Ferrero-Cadinanos, M.-L. and Delseny, M., Plant Physiol. 1986, 82, 733-738.

[20] Potter, J. W. and Clanton, C. B., Jr., Plant Physiol. 1982, 70, 590-597.

[21] Baszczynski, C. L. and Walden, D. B., Can. J. Biochem. 1982, 60, $569-579$.

[22] Ginzburg, C. and Salomon, R., Plant Physiol. 1986, 81, 259-267.

[23] Uemura, M. and Yoshida, S., Plant Physiol. 1984, 75, 818-826.

[24] Tingey, S. V. and Coruzzi, G. M., Plant. Physiol. 1987, 84, 366-373.

[25] Mayer, J. E., Hahne, G., Palme, K. and Schell, J., Plant Cell Reports $1987,6,77-81$.

[26] Dasgupta, J. and Bewley, J. D., J.Exp.Bot. 1984, 149, 1450-1459.

[27] Kenyon, W. H. and Clanton, C. B., Jr., Plant Physiol. 1986, 82, 916-924.

[28] Gallagher, S. R., Carroll, E. J., Jr. and Leonard, R. T., Plant Physiol. 1986, 81, 869-874.

[29] Meyer, Y., Aspart, L. and Chartier, Y., Plant Physiol. 1984, 75, 1034-1039.

[30] Hurkman, W. J. and Tanaka, C. K., Plant Physiol. 1986, 81, 802-806.

[31] Segers, J. Rabaey, M., de Bruyne, G., Bracke, M. and Mareel, M., in:
Dunn, M. J. (Ed.), Electrophoresis '86, VCH Verlagsgesellschaft, Weinheim, pp. 642-645.

[32] Chory, J., Voytas, D. F., Olszewski, N. E. and Ausubel, F. M., Plant Physiol. 1987, 83, 15-23.

[33] Cremer, F. and Van de Walla, C., Anal.Biochem. 1985, 147,22-26.

[34] Tymms, M. J., Gaff, D. F. and Hallam, N. D., J. Exp. Bot. 1982, 33, 332-343.

[35] de Vries, S. C., Springer, J. and Wesse]s, J. G. H., Planta 1982, 156, $129-135$

[36] Lin, C.-Y., Roberts, J. K. and Key, J. L., Plant Physiol. 1984, 74, 152-160.

[37] Bahrman, N., de Vienne, D., Thiellement, H. and Hofmann, J.-P., Biochem. Genet. 1985, 23, 247-255.

[38] Pringle, J. R., Methods Cell Biol. 1975, 12, 149-184.

[39] Gallagher, S. R. and Leonard, R. T., Plant Physiol. 1987, 83, 265-271.

[40] Malpartida, F. and Serrano, F. R., FEBS Lett. 1980, 111, 69-72.

[41] Sweadner, K. J., J. Biol. Chem. 1979, 254, 6060-6067.

[42] Addison, R. and Scarborough, G. A., J. Biol. Chem. 1981, 256, 13165-13171.

[43] Dhugga, K. S., Waines, J.G. and Leonard, R. T., Plant Physiol. 1988, $87,120-125$

[44] Ames, G. F.-L. and Nikaido, K., Biochemistry 1976, 15, 616-623.

[45] Guy, C. L. and Haskell, D., Plant Physiol. 1987, 84, 872-878.

[46] Ramagopal, S., Plant Physiol. 1987, 84, 324-331.

[47] Du Pont, F. M., Tanaka, C. K. and Hurkman, W. J., Plant Physiol. $1988,86,717-724$.

[48] Werner-Washburne, M., Cline, K. and Keegstra, K., Plant Physiol. 1983, 73, 569-575.

[49] Damerval, C. de Vienne, D., Zivy, M. and Thiellement, H., Electrophoresis 1986, 7, 52-54. 